\title{
A new percentage of biphasic calcium phosphate (BCP) of nanoparticles synthesized directly by hydrothermal process
}

\author{
Naima Rochdi *, Brahim Majidi, Nordine Habti, and Youssef Naimi \\ Laboratory of Chemistry-Physics of Materials, Faculty of Sciences Ben M'Sik B. P. 7955, Hassan II University \\ of Casablanca, Casablanca, Morocco
}

\begin{abstract}
Apatitic calcium phosphates have a mineral phase close to that of bone and are commonly used as substitutes or fillers in bone surgery. Also, they are used for their excellent biocompatibility and bioactivity. The purpose of this study is to produce directly biphasic calcium phosphate (BCP) from calcium-deficient apatite (CDHA), by the hydrothermal process. The precursors used were calcium acetate $\left(\mathrm{CH}_{3} \mathrm{COO}\right)_{2} \mathrm{Ca}$, phosphoric acid $\left(\mathrm{H}_{3} \mathrm{PO}_{4}\right)$ and triethylamine $\mathrm{N}\left(\mathrm{CH}_{2} \mathrm{CH}_{3}\right)_{3}$, the product was calcined at $900^{\circ} \mathrm{C}$. The composition phase, morphology, particle size and the molecular structure of the product were studied using these techniques: X-Ray Diffraction techniques, Scanning Electron Microscopy (SEM), Transmission Electron Microscopy, Fourier Transforms Infrared spectroscopy (FT-IR ) to reveal its phase content, Inductively Coupled Plasma-Atomic Emission Spectrometers (ICP-AES), Thermogravimetric analysis, Thermo-Differentials (ATG / ATD). The results showed that the synthesized product is CDHA. It gives after calcination at $900^{\circ} \mathrm{C}$, the biphasic calcium phosphate (a mixture of HA $+\beta-\mathrm{TCP})$. The product is also found with a new percentage and high crystallinity and nanometric size.
\end{abstract}

Keywords: Apatite deficit calcium; biphasic calcium phosphate; hydrothermal process; DRX; IF-I.

\section{Introduction}

Dentistry and orthopedics are the two great poles that dominate the use of calcium phosphate. Hydroxyapatite (HA) and beta-tricalcium phosphate $(\beta$-TCP) are two of the major types of calcium phosphate that have been widely applied in medical fields ${ }^{1,2,3}$. Due to their high biocompatibility, and similarity to the inorganic bone component and teeth in mammals ${ }^{4,5}$. BCP material combines the physicochemical properties of two elements HA and $\beta$-TCP and gives a more efficient composite material ${ }_{6,7,8}$. Recently, BCPs have been recognized as the gold standard of bone substitutes in reconstructive bone surgery ${ }^{9}$. These materials can be colonized by bone tissue, under osteogenic conditions, because of their close similarity in chemical composition to human bone ${ }^{10,11}$.

There are several methods of synthesis of calcium phosphates such as solid-state reaction, hydrothermal synthesis ${ }^{12,13}$, co-precipitation ${ }^{14}$, sol-gel method $15,16,17$, and spraying ${ }^{18}$.

Despite a large number of preparation procedures, only a few have been devoted to the synthesis of apatitic compounds with controlled morphology ${ }^{19,20}$. The technique of hydrothermal synthesis for materials has been identified as an important technology for the

*Corresponding author: Naima Rochdi

Email address: rochdi.na20@gmail.com

DOI: http://dx.doi.org/10.13171/mjc10402004221251nr synthesis of different ceramic material. Hydrothermal synthesis is a process that utilizes heterogeneous or aqueous phase reactions at high temperatures $\left(\mathrm{T}>25^{\circ} \mathrm{C}\right)$ and pressure $(\mathrm{P}>100 \mathrm{kPa})^{21}$.

The use of hydrothermal reactions for phosphate de calcium preparation gives the possibility to control the crystal face, pore structures, and its chemical composition 22; however, with hydrothermal treatment, the $\mathrm{Ca} / \mathrm{P}$ ratio for precipitates improved with increasing pressure and temperature ${ }^{23}$. Therefore, the main objective of this work is to synthesize BCP with a new percentage by hydrothermal method.

The structural characteristics of synthesized BCP will be analyzed by DRX, IR, MEB, ICP, ATG /ATD, to clarify the differences between these different components.

\section{Materials and methods}

\subsection{Preparation of sample}

The hydrothermal synthesis was carried out by various chemical reagents:

- The calcium acetate $\left(\mathrm{CH}_{3} \mathrm{COO}\right){ }_{2} \mathrm{Ca}_{2} \times \mathrm{H}_{2} \mathrm{O}$ (Merck, Germany) heated at $200^{\circ} \mathrm{C}$, for $72 \mathrm{~h}$ and, then placed in a desiccator for cooling. 
-Orthophosphoric acid $\mathrm{H}_{3} \mathrm{PO}_{4} 85 \%$ (Merck, analytical quality, Germany).

- Triethylamine $\mathrm{N}\left(\mathrm{CH}{ }_{2} \mathrm{CH}_{3}\right)_{3}$ (Riedel-de haen, purity: $99 \%$ analytical quality).

- $\mathrm{H}_{2} \mathrm{O}$ purified by Milli-Q (Millipore).

\section{Synthesis Protocol}

Anhydrous calcium acetate $\left(\mathrm{CH}_{3} \mathrm{COO}_{2}\right) \mathrm{Ca}(\mathrm{m}=23.7 \mathrm{~g})$ and orthophosphoric acid $\mathrm{H}_{3} \mathrm{PO}_{4} 85 \%(\mathrm{~m}=10.4 \mathrm{~g})$ were rapidly mixed in a Teflon container containing $40 \mathrm{ml}$ of pure water with magnetic stirring the $\mathrm{pH}=5$, the molar ratio of $\mathrm{Ca} / \mathrm{P}$ was maintained at the stoichiometric value of HA (1.67). Triethylamine $\mathrm{N}$ $\left(\mathrm{CH}_{2} \mathrm{CH}_{3}\right)_{3}$ was added dropwise to $\mathrm{pH}=8$, the mixture was stirred overnight, and then the Teflon vessel was placed in an autoclave with a volume of $100 \mathrm{ml}$, heated at temperature $200^{\circ} \mathrm{C}$, for 72 hours, and then cooled to room temperature naturally. After that, the precipitates were filtered and washed with water and dried in a laboratory oven at $80^{\circ} \mathrm{C}$ overnight.

\subsection{Characterization Techniques}

\section{X-ray diffraction analysis (XRD)}

2.2.1. The chemical composition and the degree of crystallization of the resulting powder were measured using the X-ray diffraction (XRD) method with $\mathrm{Cu}$ $\mathrm{K} \alpha$ radiation $((\lambda=1.54056 \AA)$, and the Philips Analytical PW3050 / 60 XPERT-PRO $(\theta / \theta)$ model differentiation analyzer. The diffraction patterns were recorded in the range of $\left[5,90^{\circ}\right]$ to $(2 \theta)$ in steps of $0.067^{\circ}$. The obtained spectra are compared with those of the Powder Diffraction File (PDF) of the International Center for Diffraction Data.

\subsubsection{Scanning electron microscopy}

The morphology of the powders is demonstrated by scanning electron microscopy using apparatus (SEM, JSM-5600, JEOL Ltd., Tokyo, Japan).

\subsubsection{Analysis by infrared spectrometry (FTIR)}

The infrared spectra of the powders are recorded in transmission between 400 and $4000 \mathrm{~cm}^{-1}$ at a resolution of $4 \mathrm{~cm}^{-1}$, using an FTIR (FT-IR, FT / JASCO Co., Tokyo, Japan), the samples were packaged as a dispersion in a pellet comprising $1 \%$ mixed powder and milled with $99 \% \mathrm{KBr}$.

\subsubsection{Chemical analysis}

Analysis of $\mathrm{Ca}$ and $\mathrm{P}$ and the $\mathrm{Ca} / \mathrm{P}$ molar ratio was determined by AES ICP inductively coupled plasma atomic emission spectrometry using the Optima 2000DV-AE ICP instrument, PerkinElmer Japan Co., Ltd., Japan.

2.2.5. ATG/ATD thermal analysis: The thermal analysis of synthesized powders was carried out using TG/DTA (DTG-60H SUMILTANEOU DTA-TG APPARATUS SHIMADZU", TA instruments) between room temperature to $900^{\circ} \mathrm{C}$ in argon at a heating rate of $10^{\circ} \mathrm{Cmin}^{-1}$.

\section{Results and Discussion}

\subsection{X-ray diffraction patterns}

The XRD (Figure 1a) of the powder synthesized at $200^{\circ} \mathrm{C}$ for 72 hours washed, dried at $80^{\circ} \mathrm{C}$. Overnight and uncalcined, showed narrow peaks indicating good crystallization of the product. The position of all the peaks of the spectrum is consistent with the reported data (JCPDS 01-089-6439) corresponding to the phase of apatitic calcium phosphate, and no other impurities can be found.

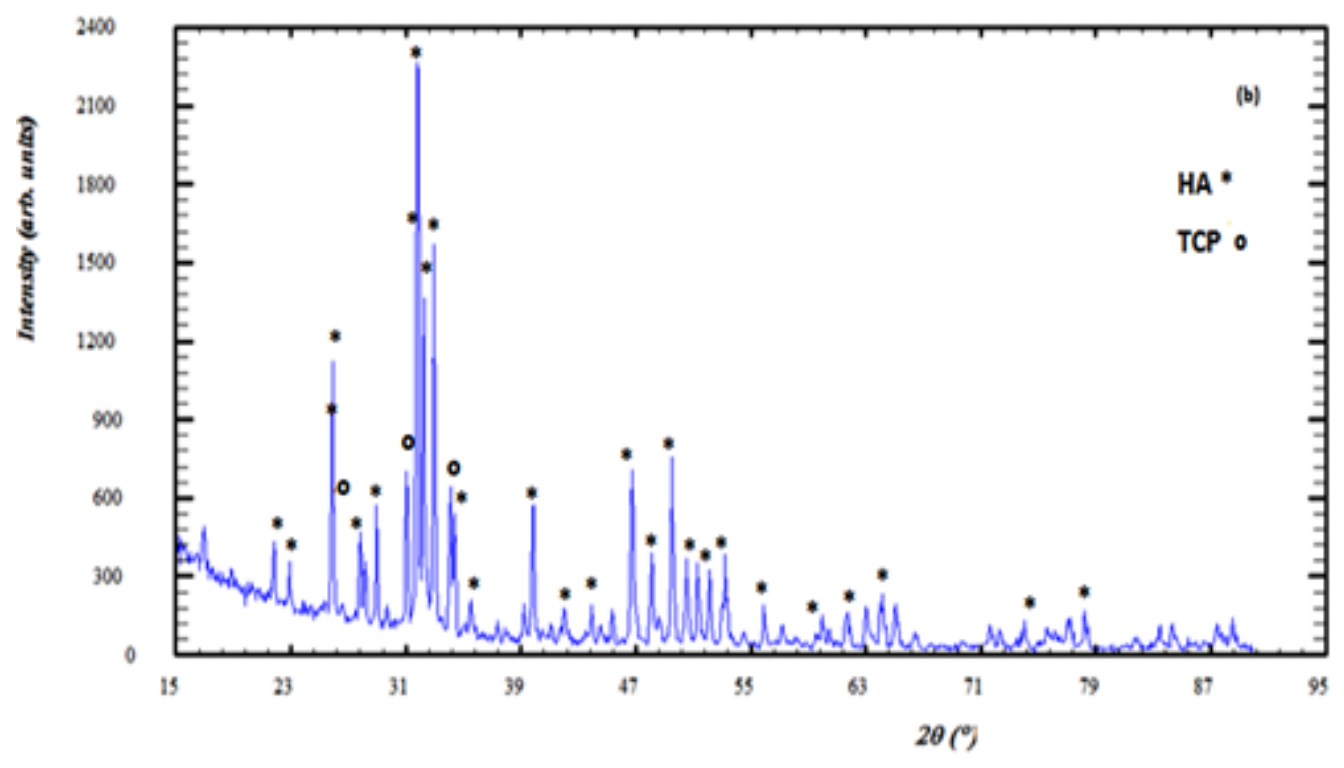




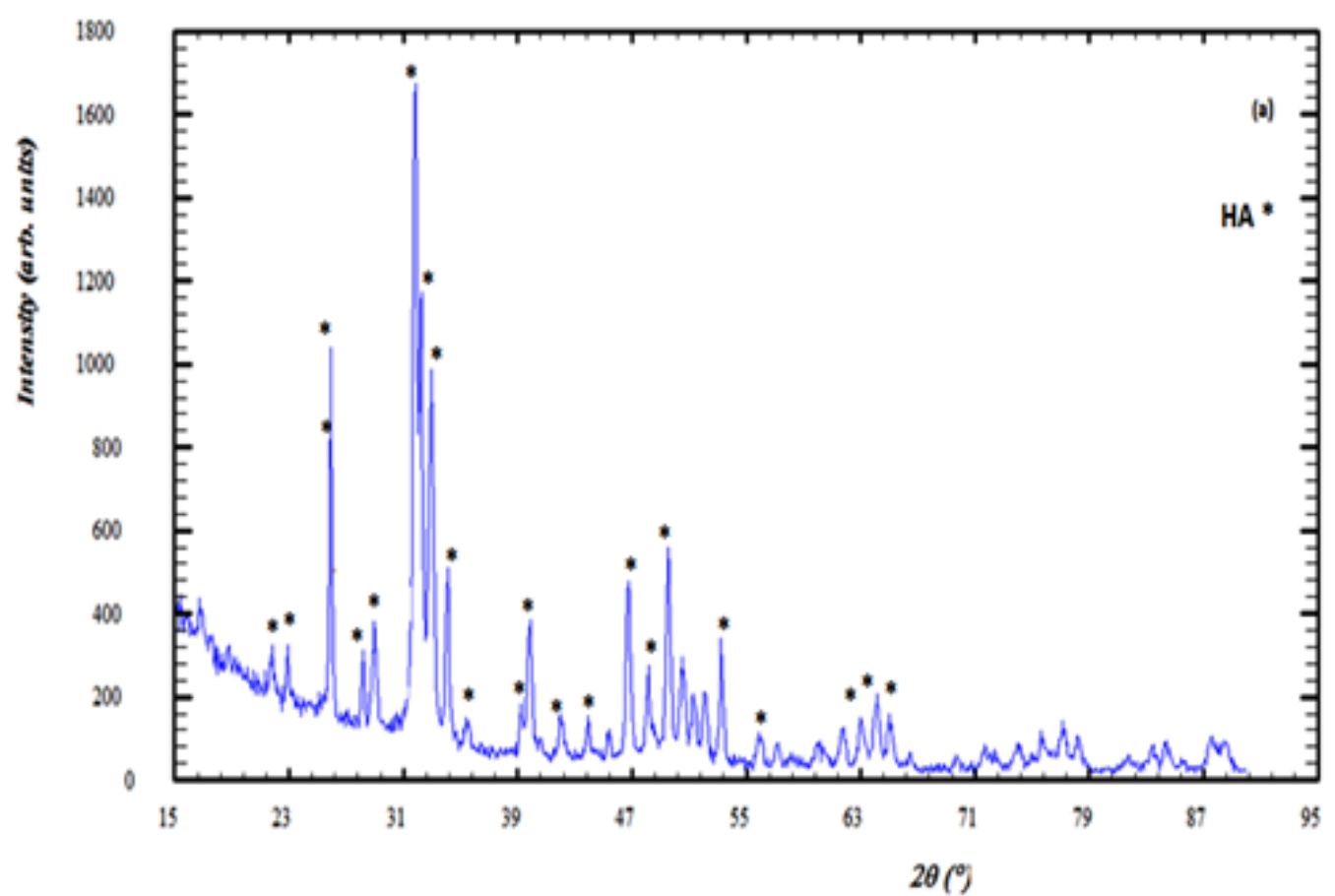

Figure 1. (a) DRX spectrum of uncalcined powder at $900^{\circ} \mathrm{C}$, (b) DRX spectrum of the same calcined powder at $900^{\circ} \mathrm{C}$ for 3 hours

Crystallinity: The size of the crystallites was determined from the Scherrer relation:

$D=\frac{K \lambda}{\beta \cdot \cos \theta}$

$\mathrm{D}$ : is the size of the crystallites, $\mathrm{k}$ : the shape constant $(\mathrm{K}=0.9)$

$\lambda=1.54 \AA$ the wavelength of the X-rays $(\mathrm{Cu} \mathrm{K} \alpha)$

$\beta$ : is the mid-height width of a line.

The measurements were carried out on DRX peaks allowing calculation of D (size of the crystallites) along two perpendicular axes: along with the axis c according to the reflection (002) and perpendicular to the axis c according to the reflection (310).

The values found showed that the crystallites of the uncalcined product have an elongated shape along the c axis (D (002) / D (310)> 1), whereas the crystallites of the calcined product have an almost spherical shape $(002) / \mathrm{D}(310)=0.98 \approx 1)$.

(310)> 1), whereas the crystallites of the calcined product have an almost spherical shape (002) / D $(310)=0.98 \approx 1)$.

Table 1. Size of the crystallites of the powders before and after calcination at $900^{\circ} \mathrm{C}$.

\begin{tabular}{|c|c|c|c|}
\hline & $\mathbf{D}_{(\mathbf{0 0 2})}(\mathbf{n m})$ & $\mathbf{D}_{(\mathbf{3 1 0})}(\mathbf{n m})$ & $\mathbf{D}_{\mathbf{( 0 0 2 )}} / \mathbf{D}_{(\mathbf{3 1 0})}$ \\
\hline Powder before calcination & 41 & 32 & 1,3 \\
\hline Powder after calcination & 41 & 42 & $0,98 \approx 1$ \\
\hline
\end{tabular}

\subsection{Infrared spectroscopy}

FTIR spectroscopy was used to study the powders in the as-prepared state and the after heat treatment at $900^{\circ} \mathrm{C}$ for 3 hours state to verify the results and also to quantify the effect of treatment on the different functional groups, such as hydroxyl and phosphate groups, of hydroxyapatite. Figure $2(\mathrm{a}, \mathrm{b})$ shows the FTIR spectra of as-prepared HA, respectively; the spectra of the prepared materials were found to be very similar. A two-bands of $\mathrm{OH}^{24,25,26,27}$, A weak band at $3571 \mathrm{~cm}^{-1}$ is partially obscured by broadband between $2800-3500 \mathrm{~cm}^{-1}$, which is characteristic of moisture in the sample and a second band at $634 \mathrm{~cm}^{-1}$. The phosphate $v_{3}$ and $v_{1}$ bands were identified by three peaks (at 1094, 1032, and $960 \mathrm{~cm}^{-1}$ ) and the $v_{4}$ band by two peaks (at 603 and $563 \mathrm{~cm}^{-1}$ ). The carbonate $v_{3}$ band also was observed as peaks at $\left(1384 \mathrm{~cm}^{-1}\right)$ and the carbonate $v_{2}$ band as a single peak (at $875 \mathrm{~cm}^{-1}$ ). 


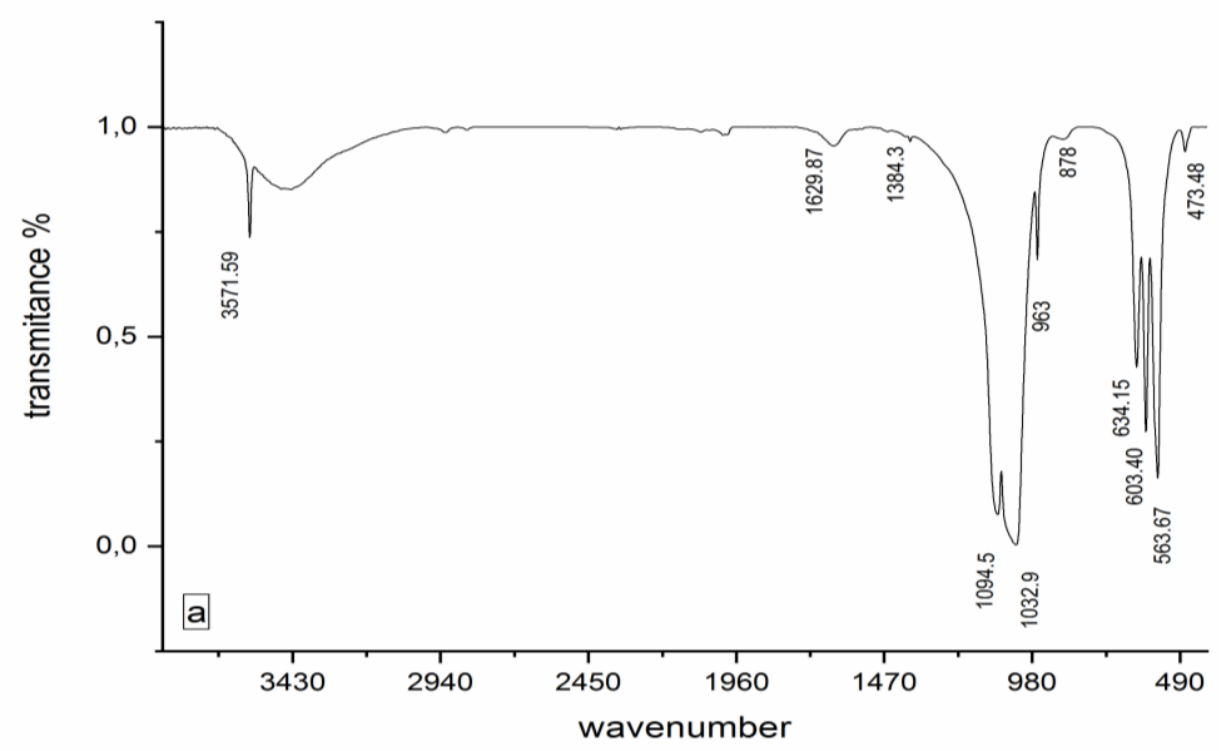

Figure 2. (a) IR spectrum of the uncalcined powder

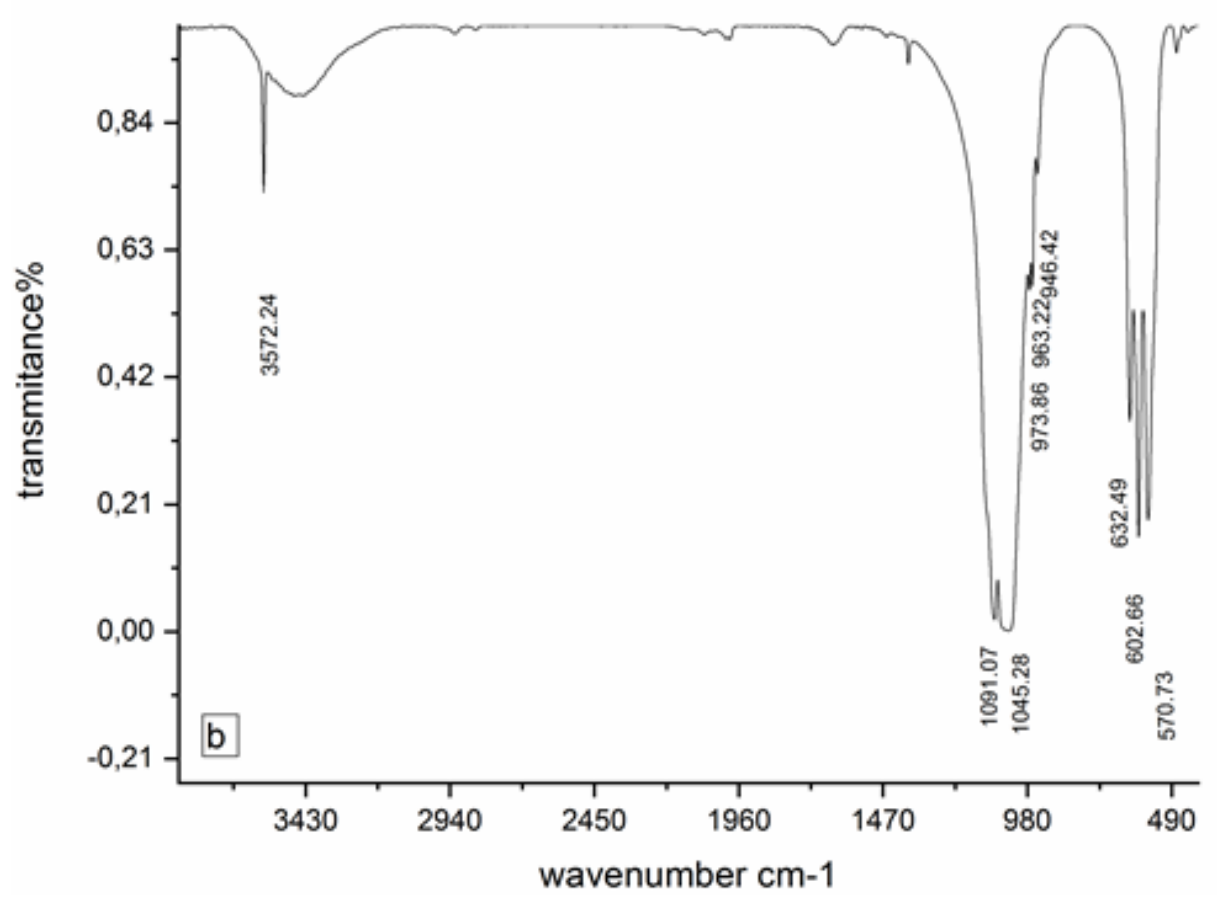

Figure 2. (b) IR spectrum of the same powder calcined at $900^{\circ} \mathrm{C}$ for $3 \mathrm{~h}$

The FTIR spectra calcined at $900^{\circ}$ Csamples showed several significant changes from the as-prepared samples (Figure 2 (b)).

The broadband due to moisture in the sample disappeared, and the $\mathrm{OH}$ band in heat-treated samples appeared as a very sharp peak. The clear peaks that corresponded to carbonate (1384 and $\left.875 \mathrm{~cm}^{-1}\right)$ in the FTIR spectra of the as-prepared samples (Figure 2 (a)) disappeared in the heat-treated samples. The FTIR spectra of the heat-treated samples exhibited peaks at 946 and $974 \mathrm{~cm}^{-1}$ attributed to $\mathrm{PO}_{4}$ of $\beta$-TCP ${ }^{28,29}$ (iii) reduction of the intensity of the peak at $571 \mathrm{~cm}^{-1}$. In both IR spectra, a good resolution of the bands at about $563 \mathrm{~cm}^{-1}$ to $634 \mathrm{~cm}^{-130}$ was observed for both samples attesting good crystallinity of the noncalcined products and calcined at $900^{\circ} \mathrm{C}$.

\subsection{Scanning electron microscopy (SEM)}

The SEM micrographs are shown in Figure $3(a, b)$ the product before calcination, showed that the needleshaped particles easily form an aggregated crystal. The product after calcination shows particles in circular or spherical form. The agglomerates were of an irregular shape with a size between $1.056 \mu \mathrm{m}$ and $2.18 \mu \mathrm{m}$. The form adopted after the treatment is a circular shape; our results are in agreement with those of the Landi team ${ }^{31}$. 

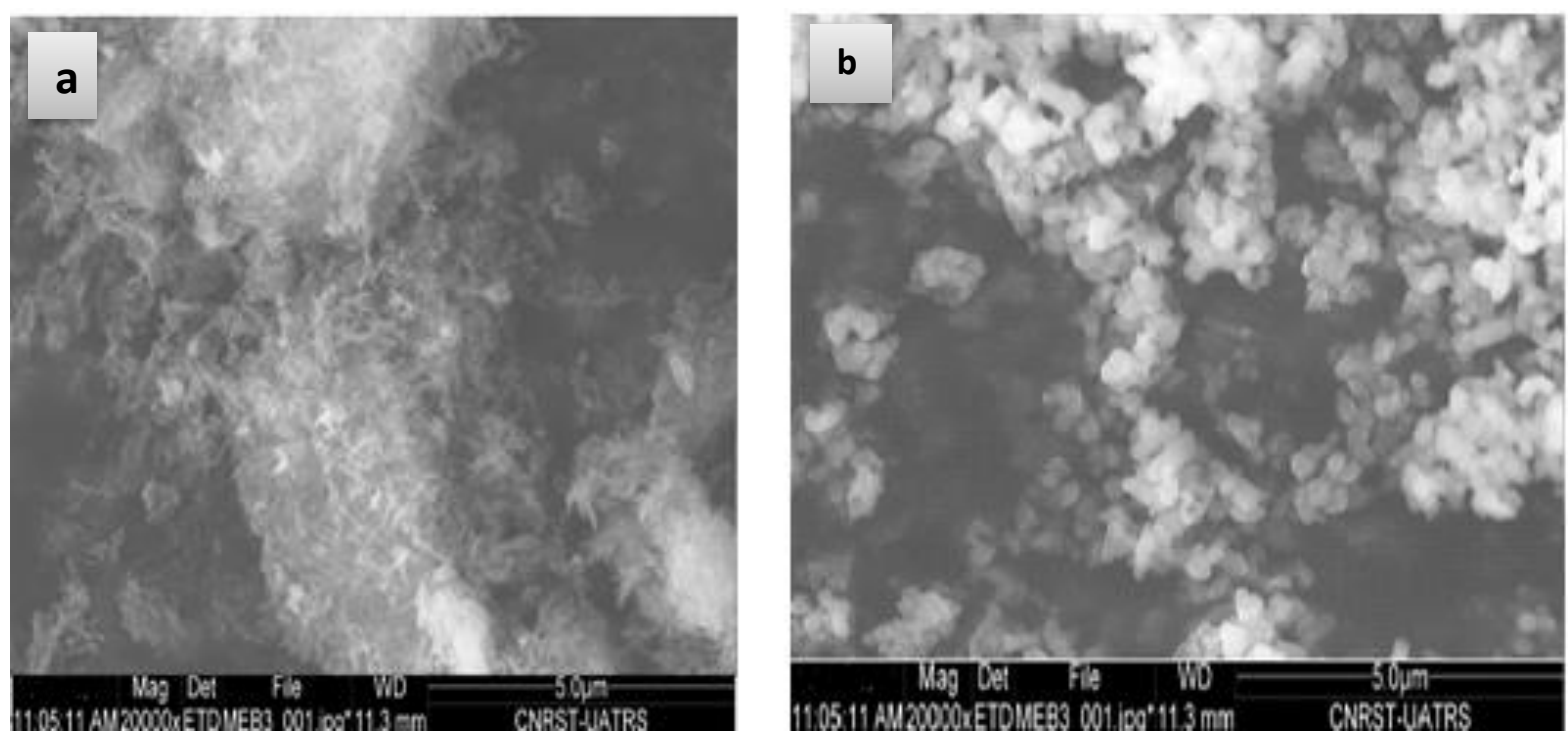

Figure 3. Scanning electron micrographs of the product synthesized at (a) Unicalcined sample, $200^{\circ} \mathrm{C}$ and (b) Calcined sample, $3 \mathrm{~h}, 900^{\circ} \mathrm{C}$

\subsection{Determination of $\mathrm{Ca} / \mathrm{P}$ ratio}

The ICP-AES analysis showed that the molar ratio $\mathrm{Ca} / \mathrm{P}$ of the non-calcined product equal to 1.60 . This value is between 1.5 and 1.67. It represents the molar ratios $(\mathrm{Ca} / \mathrm{P})$ of $\beta$-TCP and stoichiometric hydroxyapatite ${ }^{32}$. The calcined product has a molar ratio $\mathrm{Ca} / \mathrm{P}=1.7$ higher than 1.67 that of the stoichiometric hydroxyapatite.

The chemical content of $\mathrm{Ca}$ and $\mathrm{P}$ and the $\mathrm{Ca} / \mathrm{P}$ molar ratio of the as-synthesized powders.

Table 2. Chemical analysis determined by ICP-MS.

\begin{tabular}{|c|c|c|c|}
\hline & $\mathbf{C a}(\mathbf{w t} \boldsymbol{\%})$ & $\mathbf{P}(\mathbf{w t} \boldsymbol{\%})$ & $\mathbf{C a} / \mathbf{P}$ \\
\hline $\mathbf{E}$ & 37.3 & 17.97 & 1.6 \\
\hline $\mathbf{E}^{*}$ & 39.70 & 18.05 & 1.7 \\
\hline
\end{tabular}

\subsection{Thermogravimetric analysis and differential} thermal analysis (ATG / ATD)

The thermal behavior of the uncalcined product was investigated by ATD / ATG; the thermograms are shown in Figure $4(\mathrm{a}, \mathrm{b})$. The powder was heated from room temperature to $900^{\circ} \mathrm{C}$ under a stream of air with a rate of temperature rise equal to $10^{\circ} \mathrm{C} / \mathrm{min}$. Analysis of the ATG curve shows a total mass loss (expressed as a mass fraction) of about 5.5\%, distributed over the following temperature ranges (Table 3).

Table 3. Total mass loss (expressed as a mass fraction) of the product distributed in different temperature ranges.

\begin{tabular}{|c|c|c|}
\hline & $\begin{array}{c}\text { A loss of mass } \\
\text { in \% by weight }\end{array}$ & Origin of $\mathbf{H}_{2} \mathbf{O}$ \\
\hline $\mathbf{3 0}^{\circ} \mathbf{- \mathbf { 1 0 0 } ^ { \circ }}$ & 1.40 & $\mathrm{H}_{2} \mathrm{O}$ of physisorption ${ }^{33,34}$ \\
\hline $\mathbf{1 0 0}^{\circ} \mathbf{- 2 5 0}^{\circ}$ & 0.66 & $\mathrm{H}_{2} \mathrm{O}$ of physisorption + certain amount of chemisorption $\mathrm{H}_{2} \mathrm{O}$ \\
\hline $\mathbf{2 5 0}^{\circ}-\mathbf{3 0 0}^{\circ}$ & 1.99 & $\mathrm{H}_{2} \mathrm{O}$ of chemisorption \\
\hline $\mathbf{3 0 0}^{\circ}-\mathbf{6 8 0}^{\circ}$ & 0.97 & $\mathrm{H}_{2} \mathrm{O}$ of the condensation of $\mathrm{HPO}_{4}$ to $\mathrm{P}_{2} \mathrm{O}_{7}$ \\
\hline $\mathbf{6 8 0}^{\circ} \mathbf{- 9 0 0}^{\circ}$ & 0.47 & $\mathrm{H}_{2} \mathrm{O}$ of the reaction of $\mathrm{P}_{2} \mathrm{O}_{7}$ with $\mathrm{OH}$ of hydroxyapatite \\
\hline
\end{tabular}

The ATD curve; for powder was represented in (Figure 4.b), indicates the thermal phenomena associated with the different mass losses of $\mathrm{H}_{2} \mathrm{O}$. The first endothermic peak ranges from ambient temperature to $300^{\circ} \mathrm{C}$ corresponds to the departure of the water of physisorption. The second endothermic peak between $350^{\circ}$ and $650^{\circ}$ indicates the departure of water from the condensation of the $\mathrm{HPO}_{4}$ group into $\mathrm{P}_{2} \mathrm{O}_{7}$. The final endothermic peak between $650^{\circ} \mathrm{C}$ and $900^{\circ} \mathrm{C}$ shows a water outlet product of the thermal reaction between $\mathrm{P}_{2} \mathrm{O}_{7}$ and $\mathrm{OH}$ of hydroxyapatite. 

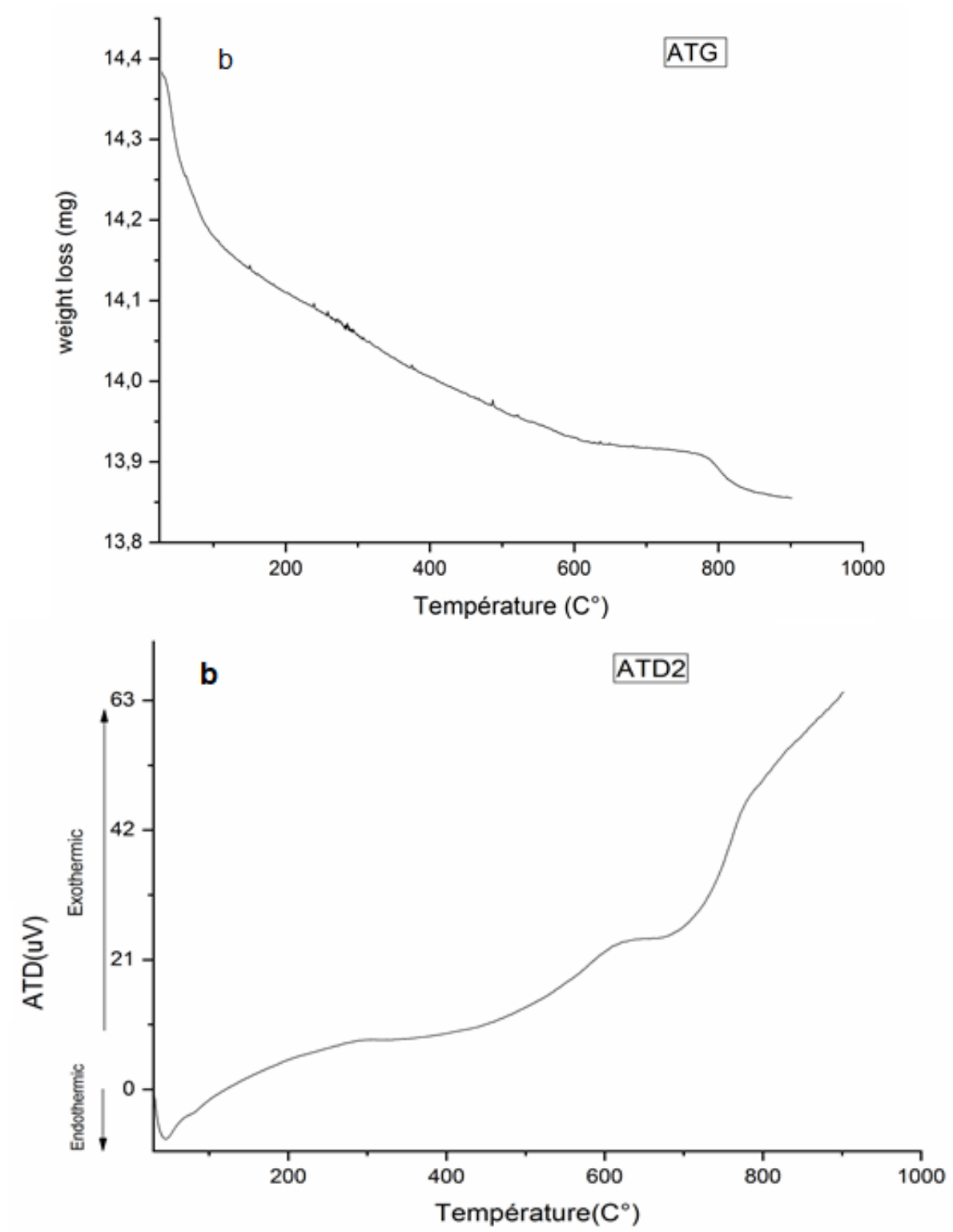

Figure 4. (a, b) ATG / ATD for sample E1

\section{Discussion}

The results of the various methods of characterization and analysis show that the synthetic product is calcium-deficient hydroxyapatite (CDHA), which is distinguished by a $\mathrm{Ca} / \mathrm{P}$ ratio of $1.60(1.50<\mathrm{Ca} / \mathrm{P}$ $<1.67)$ and confirmed by X-ray diffraction analysis and by the presence of $\mathrm{HPO}_{4}$ group observed by infrared spectroscopy at $875 \mathrm{~cm}^{-1}$. This is in agreement with the results of S. Raynaud et al. ${ }^{35}$, who studied the influence of the $\mathrm{Ca} / \mathrm{P}$ ratio on the synthesis of apatitic calcium phosphates.

The heating at $900^{\circ} \mathrm{C}$, for 3 hours of the synthesized product, results in the formation of a biphasic product composed of HA and $\beta-\mathrm{TCP}^{36,37}$. The infrared shows the disappearance of the peak at $875 \mathrm{~cm}^{-1}$ corresponding to the HPO4 group and the appearance of new peaks at $946 \mathrm{~cm}^{-1}$ and $974 \mathrm{~cm}^{-1}$ corresponding to the vibration of the $\mathrm{PO} 4$ group of $\beta$. This last result conforms to the DRX spectrum of the stoichiometric hydroxyapatite and is verified by the $\mathrm{Ca} / \mathrm{P}$ molar ratio $=1.7$ determined by ICP-AES. .
The ATG / ATD thermal behavior of the synthesis product confirms the transformation of the CDHA in biphasic products (BCP). This transformation is manifested by the appearance of two characteristic endothermic phenomena. The first one being observed between $300^{\circ} \mathrm{C}$ and $680^{\circ} \mathrm{C}$. with a $0.97 \%$ mass loss corresponding to the condensation of the $\mathrm{HPO}_{4}$ groups in $\mathrm{P}_{2} \mathrm{O}_{7}$ according to the reaction ${ }^{38}$.

\section{$2 \mathrm{HPO}_{4}^{-2} \longrightarrow \mathrm{P}_{2} \mathrm{O}_{7}^{-4}+\mathrm{H}_{2} \mathrm{O}$}

The second between $700^{\circ} \mathrm{C}$ and $900^{\circ} \mathrm{C}$. Corresponding to the thermal reaction between the $\mathrm{P}_{2} \mathrm{O}_{7}$ group and the hydroxyl group $\mathrm{OH}$ of the hydroxyapatite to form the $\mathrm{PO}_{4}$ groups of the $\beta$-TCP according to the reaction mechanism:

\section{$\mathrm{P}_{2} \mathrm{O}_{7}{ }^{4-}+2 \mathrm{OH} \quad \longrightarrow \quad 2 \mathrm{PO}_{4}{ }^{3-}+\mathrm{H}_{2} \mathrm{O}$}

After calcination, our product undergoes heat transformation, which leads to the formation of stoichiometric hydroxyapatite and $\beta-\mathrm{TCP}^{39}$ according to the reaction: 


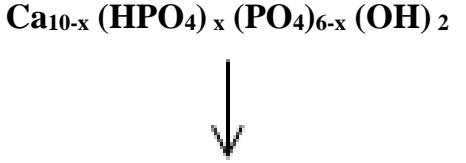

\section{(1-x) $\mathrm{Ca}_{10}\left(\mathrm{PO}_{4}\right)_{6}(\mathrm{OH})_{2}+3 \mathrm{xCa}_{3}\left(\mathrm{PO}_{4}\right)_{2}+\mathrm{xH}_{2} \mathrm{O}$}

The synthesis product has the chemical formula $\mathrm{Ca}_{(10-x)} \mathrm{HPO}_{4}(\mathrm{x}) \mathrm{PO}_{4}(6-\mathrm{x}) \mathrm{OH}(2-\mathrm{x})$ with $0<\mathrm{x}<1$, the value of $\mathrm{x}$ has been estimated at $\mathrm{x}=$ the formalism applied by $\mathrm{M}$. Vallet-Regi et al. The product has the formula ${ }^{37}: \mathrm{Ca}_{9.96}\left(\mathrm{HPO}_{4}\right)_{0.04}\left(\mathrm{PO}_{4}\right)_{5.96}(\mathrm{OH})_{0.96}$.

The weight percentage of the biphasic mixture $(\mathrm{HA}+\beta$-TCP $)$ of the calcined product calcined at $900^{\circ} \mathrm{C}$. is determined by the relationship obtained by S. Raynaud et al. which gives the following values:\% $\mathrm{HA}=96 \%$ and $\% \beta$-TCP $=4 \%$ This is in agreement with the result of $\mathrm{S}$. Raynaud et al.

\section{Conclusion}

Nanoparticles of phosphate calcium biphasic of good purity, the form of a needle were successfully prepared directly by the hydrothermal method at $200^{\circ} \mathrm{C}$, for 72 hours from a reaction mixture composed of calcium acetate, phosphoric acid, and triethylamine. The synthesis product calcined at $900^{\circ} \mathrm{C}$ for 3 hours leads to the formation of biphasic calcium phosphate (BCP) with high crystallinity and with a new percentage $96 \%$ HA and $4 \% \beta$-TCP.

\section{Acknowledgements}

The authors would like to thank all those who have helped in this work from near or far.

\section{References}

1- J. A. Stammeier, B. Purgstaller, D. Hippler, V. Mavromatis, M. Dietzel, In-situ Raman spectroscopy of amorphous calcium phosphate to crystalline hydroxyapatite transformation, MethodsX, 2018, 5, 1241-1250.

2- D. S. Metsger, T. D. Driskell, J. R. Paulsrud, Tricalcium phosphate ceramic - a resorbable bone implant: review and current status, $J \mathrm{Am}$ Dent Assoc, 1982, 105, 1035-1038.

3- W. Habraken, P. Habibovic, M. Epple, M. Bohner, Calcium phosphates in biomedical applications: materials for the future?, Mater Today, 2016, 19, 69-87.

4- D.-M. Liu, H.-M. Chou, Formation of a new bioactive glass-ceramic, J Mater Sci Mater Med, 1994, 5, 7-10.

5- R. Murugan, S. Ramakrishna, Bioresorbable composite bone paste using polysaccharide-based nano-hydroxyapatite, Biomaterials, 2004, 25, 3829-3835.

6- S. V. Dorozhkin, Multiphasic calcium orthophosphate $\left(\mathrm{CaPO}_{4}\right)$ bioceramics and their biomedical applications, Ceram Int, 2016, 42, 6529-6554.
7- I. Denry, L. T. Kuhn, Design, and characterization of calcium phosphate ceramic scaffolds for bone tissue engineering, Dent Mater, 2016, 32, 43-53.

8- C. Schwartz, M. Vautrin, Phosphocalcium ceramics are efficient in the management of severe acetabular loss in revision hip arthroplasties. A 22 cases long-term follow-up study, Eur J Orthop Surg Traumatol, 2015, 25, 227-232.

9- J. M. Bouler, P. Pilet, O. Gauthier, E. Verron, Biphasic calcium phosphate ceramics for bone reconstruction: A review of biological response, Acta Biomater, 2017, 53, 1-12.

10-M. Descamps, O. Richart, P. Hardouin, J. C. Hornez, A. Leriche, Synthesis of macroporous $\beta$ tricalcium phosphate with controlled porous architectural, Ceram Int, 2008, 34, 1131-1137.

11-P. Ducheyne, Q. Qiu, Bioactive ceramics: the effect of surface reactivity on bone formation and bone cell function, Biomaterials, 1999, 20, 2287-2303.

12-I. S. Neira, Y. V. Kolen'ko, O. I. Lebedev, G. Van Tendeloo, H. S. Gupta, F. Guitián, M. Yoshimura, An Effective Morphology Control of Hydroxyapatite Crystals via Hydrothermal Synthesis, Cryst Growth Des, 2009, 9, 466-474.

13-M. Okada, T. Matsumoto, Synthesis and modification of apatite nanoparticles for use in dental and medical applications, Jpn Dent Sci Rev, 2015, 51, 85-95.

14-S. Rujitanapanich, P. Kumpapan, P. Wanjanoi, Synthesis of Hydroxyapatite from Oyster Shell via Precipitation, Energy Procedia, 2014, 56, 112-117.

15-G. J. Owens, R. K. Singh, F. Foroutan, M. Alqaysi, C.-M. Han, C. Mahapatra, H.-W. Kim, J. C. Knowles, Sol-gel-based materials for biomedical applications, Prog Mater Sci, 2016, 77, 1-79.

16-M. H. Fathi, A. Hanifi, Evaluation and characterization of nanostructure hydroxyapatite powder prepared by simple sol-gel method, Mater Lett, 2007, 61, 3978-3983.

17-M. H. Fathi, A. Hanifi, V. Mortazavi, Preparation and bioactivity evaluation of bone-like hydroxyapatite nanopowder, J Mater Process Technol, 2008, 202, 536-542.

18-R. Narayanan, S. K. Seshadri, T. Y. Kwon, K. H. Kim, Calcium phosphate-based coatings on titanium and its alloys, $J$ Biomed Mater Res $B$ Appl Biomater, 2008, 85, 279-299.

19-M. Yoshimura, H. Suda, K. Okamoto, K. Ioku, Hydrothermal synthesis of biocompatible whiskers, J Mater Sci, 1994, 29, 3399-3402.

20-M. Sadat-Shojai, M.-T. Khorasani, E. DinpanahKhoshdargi, A. Jamshidi, Synthesis methods for nanosized hydroxyapatite with diverse structures, Acta Biomater, 2013, 9, 7591-7621. 
21-A. K. Nayak, Hydroxyapatite Synthesis Methodologies: An Overview, Int. J. ChemTech Res, 2010, 2, 903-907.

22-K. Ioku, M. Kamitakahara, Hydroxyapatite Ceramics for Medical Application Prepared By Hydrothermal Method, Phosphorus Res Bull, 2009, 23, 25-30.

23-M. Sadat-Shojai, Preparation of hydroxyapatite nanoparticles: comparison between hydrothermal and solvo-treatment processes and colloidal stability of produced nanoparticles in a dilute experimental dental adhesive, J Iran Chem Soc, 2009, 6, 386-392.

24-T. Amna, Valorization of Bone Waste of Saudi Arabia by Synthesizing Hydroxyapatite, Appl Biochem Biotechnol, 2018, 186, 779-788.

25-H. Chen, B. H. Clarkson, K. Sun, J. F. Mansfield, Self-assembly of synthetic hydroxyapatite nanorods into an enamel prism-like structure, J Colloid Interface Sci, 2005, 288, 97-103.

26-K. Lin, J. Chang, R. Cheng, M. Ruan, Hydrothermal microemulsion synthesis of stoichiometric single-crystal hydroxyapatite nanorods with mono-dispersion and narrow-size distribution, Mater Lett, 2007, 61, 1683-1687.

27- Y. Sun, G. Guo, Z. Wang, H. Guo, Synthesis of single-crystal HAP nanorods, Ceram Int, 2006, 32, 951-954.

28-M. S. Arsad, P. M. Lee, L. K. Hung, Synthesis and characterization of hydroxyapatite nanoparticles and $\beta$-TCP particles, In, 2nd international conference on the biotechnology and food science, 2011, 7, 184-188.

29-B. Chen, Z. Zhang, J. Zhang, Q. Lin, D. Jiang, Fabrication and mechanical properties of $\beta$-TCP pieces by gel-casting method, Mater Sci Eng $C$, 2008, 28, 1052-1056.

30-G. Felício-Fernandes, M. Laranjeira, Calcium phosphate biomaterials from marine algae. Hydrothermal synthesis and characterization, Quimica Nova, 2000, 23, 441-446.
31-E. Landi, A. Tampieri, G. Celotti, S. Sprio, Densification behavior and mechanisms of synthetic hydroxyapatites, J Eur Ceram Soc, 2000, 20, 2377-2387.

32-K. Ozeki, Y. Fukui, H. Aoki, Influence of the calcium phosphate content of the target on the phase composition and deposition rate of sputtered films, Appl Surf Sci, 2007, 253, 5040-5044.

33-S. Kongsri, K. Janpradit, K. Buapa, S. Techawongstien, S. Chanthai, Nanocrystalline hydroxyapatite from fish scale waste: Preparation, characterization, and application for selenium adsorption in aqueous solution, Chem Eng J, 2013, 215-216, 522-532.

34-M. Markovic, B. O. Fowler, M. S. Tung, Preparation and comprehensive characterization of a calcium hydroxyapatite reference material, $J$ Res Natl Inst Stand Technol, 2004, 109, 553-568.

35-S. Raynaud, E. Champion, D. BernacheAssollant, P. Thomas, Calcium phosphate apatites with variable $\mathrm{Ca} / \mathrm{P}$ atomic ratio $\mathrm{I}$. Synthesis, characterization and thermal stability of powders, Biomaterials, 2002, 23, 1065-1072.

36-K. Ishikawa, P. Ducheyne, S. Radin, Determination of the $\mathrm{Ca} / \mathrm{P}$ ratio in calciumdeficient hydroxyapatite using X-ray diffraction analysis, J Mater Sci Mater Med, 1993, 4, 165-168.

37-R. Z. LeGeros, Calcium phosphates in oral biology and medicine, Karger: Basel ; New York, 1991.

38-W. Suchanek, M. Yoshimura, Processing and properties of hydroxyapatite-based biomaterials for use as hard tissue replacement implants, $J$ Mater Res, 1998, 13, 94-117.

39-M. Valletregi, Synthesis, and characterization of calcium-deficient apatite, Solid State Ion, 1997, 101-103, 1279-1285. 